\title{
The Impact of Brand Country-of-Origin Image on the Formation of Brand Equity in the Sports Apparel Industry
}

\author{
Rasoul Azadi", Bahram Yousefi, Hossein Eydi \\ Department of Physical Education and Sport Science, University of Razi, Iran
}

Copyright (C) 2015 by authors, all rights reserved. Authors agree that this article remains permanently open access under the terms of the Creative Commons Attribution License 4.0 International License

\begin{abstract}
The present study aimed to investigate the conducted effects of the Brand Country-of-Origin Image on The Formation of Brand Equity in the sports apparel industry. Method of this study is descriptive-correlative. The study investigated the effects among the research variables using structural equation model (SEM) with Lisrel software. The population of the study was the whole country's physical education students, alumni, which 805 subjects were selected based on the purposive sampling, using in person, and online questionnaires were collected from Iran. The results showed that the image of the country of origin has a positive relation to the brand equity dimension including brand loyalty, Perceived quality, and brand Awareness/associations, and there is a significant positive relation between brand equity dimensions and brand equity. Therefore, it is recommended to manufacturers in the apparel and sports equipment to try to promote brand's country of origin image to increase brand image in markets by using advertisements and other combined components such as personal sales and public relations.
\end{abstract}

Keywords Brand Equity, Country of Origin Image, Sports Clothing, Iran

\section{Introduction}

Today, sport and recreation has undergone many changes and from a simple form of games and entertainments transfers to multibillion-dollar industry and one of the largest money making economic segment of this century [1]. In the past few decades the industry is poised for growth, such that it can be, Growth of the clothing and sports equipment named. Sportswear is an important part of the sports products market, which been defined as clothing and shoes made for sports participation. Although now it includes clothing that people wear for everyday activities [2]. Today, we see that sports consumers are buying sports goods from the stores which all items been supplied (clothing, sports equipment and...). Facing with massive abundance of products that are identical in terms of quality and shape, Consumers' purchasing decisions will be push towards brand without considering the characteristics of the products [3]. In the markets, which products and services, increasingly overlap and adapt, a strong brand can be the only display characteristic that distinguishes a product or service offerings from competitors [4]. To achieve this goal, one of the most popular marketing concepts, which over the past twenty years, from academics and marketers, have been studied, the brand equity. "brand equity" Refers to the tremendous value that the brand name brings to the producers, retailers and consumers of the brand. The equity of a brand is the result of consumers' perception of it which is influenced by many factors. Brand equity cannot be fully understood without carefully examining its sources, that is, the contributing factors to the formation of brand equity in the consumers' mind. Most of the brand equity research focuses on the marketing mix variables such as advertising, distribution, price and product quality as the contributing factors [5]. However, not much attention is given to the non-marketing mix factors. In the process of buying, consumers are not only concern about the quality and price of a product but also other factors such as the brand's country-of-origin. Many consumers use country-of-origin stereotypes to evaluate products for example, "Japanese electronics are reliable", "German cars are excellent", "Italian pizza are superb". Many consumers believe that a "Made in ..." label means a product is "superior" or "inferior" depending on their perception of the country. Brands from countries that have a favorable image generally find that their brands are readily accepted than those from countries with less favorable image [6].

\subsection{Literature Review \\ 1.1.1. Brand's Country of Origin}

Today, every company that competes in world market 
produces and distributes products in worldwide customer's familiarity with the name of manufacturer country has an effect on image of that product or commercial name [7]. This association of brand's country of origin from consumer's viewpoint can influence brand dimensions and brand equity from consumer's viewpoint in a special country. A suitable perception of a country leads to a suitable perception of product's characteristics such as quality. Brand's country of origin influences consumer's evaluation. Consumer's evaluation is determined through effect of original manufacturer's expertise. In spite of willingness to his/her nationality, culture, customs, consumer tend to be influenced by those brand which produce more added value for them. The effects of brand's country of origin can be an intangible barrier for products which are entering [8].

\subsubsection{Brand Equity}

Based on first definition of Brand equity by Farquhar, Brand equity is an added value which brand gives to a product [9].Aaker (1991) defines Brand equity as follows: A set of five groups of properties and commitment related to brand. Its name and symbol adds or reduces the value regarding a product or presented service to a company or customers. According to Lasar et al (1995), brand equity has been tested from consumer's viewpoint and financial perspective. In other words, financial concept discusses from viewpoint of brand, and customer based concept is the brand equity for consumer which is the result of marketing decision making [10]. High brand equity is a competitive advantage, because based on the company can determine high prices for its products create better leverage, increase sales and profit margin, and reduce its vulnerability in competition [11]. In other words high brand equity produces more distinctiveness, more brand knowledge and better consumer response [12].which leads to better brand performance from two financial and consumer viewpoints.

Brand equity can help customer to interpret, process, and store large body of information related to product and brand, also can influence consumer's reliability in buying decision, because the customer experienced it before and is familiar with brand and its characteristics. The important thing is the perceived equity and related issues which can increase the customer's sat is faction after experiencing the product [13].

\subsubsection{Brand Equity and Its Dimensions}

Aaker (1991) proposed a model showed that dimensions of brand equity include four important dimensions of brand loyalty, brand awareness, perceived equity, and brand association. Kapferer's brand equity Model has been proposed based on this assumption that brand equity is a tacit contract between brand and customers in which a set of equalities are exchanged between them for automatic repetitive buying. Brand produces satisfaction for producer and consumer by reducing the risk of transaction According to kapferer brand identifies and guaranties supply and frames and then stabilizes it. They owe their value to their capability for reducing risk and uncertainty [14]. Accordingly, consumer-based brand equity dimensions consist of brand awareness, perceived quality, brand associations, and brand loyalty $[13,15]$.

Brand awareness is defined as "the ability of the potential buyer to recognize and recall that a brand is a member of a certain product category [13]. Whereas, Keller (1993) stated that brand awareness is "related to the likelihood that a brand name will come to mind and the ease with which it does so". Keller (1993, 2008) stressed that without being aware of, and familiar with the brand, building strong and favorable brand image will not be possible. Perceived quality is a key dimension of brand equity. Aaker (1991) and Keller (2003) defined it as "the customer's perception of the overall quality or superiority of a product or service with respect to its intended purpose, relative to alternatives". Brand associations and brand image have been used interchangeably in the literature. According to Aaker (1991), brand image is "anything linked in memory to a brand, usually in some meaningful way" [13]. Finally, brand loyalty as a behavioral dimension is "a measure of the attachment a customer has to a brand" (Aaker, 1991), which in turn results in frequent purchases of the brand [17]. Yet from an attitudinal perspective, Yoo and Donthu (2002) [18] described it as "the tendency to be loyal to a focal brand, which is demonstrated by the intention to buy the brand as a primary choice" [19].

\subsubsection{Brand's country-of-origin image and brand equity}

In the existing literature, there is a proliferation of studies to document country-of-origin perspectives. From these studies, marketers and consumer behavior researchers generally accept that a product's or brand's country-of-origin is an important influencing factor in consumer decision-making [20]. Most of the previous studies suggest that country-oforigin information which is indicated by the "Made in ..."label serves several purposes in consumer decision-making. It act as a salient attribute in consumer product evaluation, stimulates consumer's interest in the product, affect behavioral intentions through social norms and influences buyer behavior through affective processes as in the case of consumer's patriotic feelings about their own country. The overall evaluation of products is influenced by country stereotyping, that is, the image that consumers have about a certain country will influence their perceptions of products from that country. Since consumers' perception of a particular country-of-origin influence their evaluation of products from that country, this will influence their preference, purchase intention and choice of a particular brand. Obviously, this has implications on the brand's equity [6].

\subsection{Literature of Research}

Many studies revealed associations between consumer-based brand equity dimensions and brand equity in different contexts and diverse cultures.

Results Pappu et al (2006) indicated that the consumer-based equity of a brand was significantly 
associated with both the macro and micro images of the country of origin of the brand. The relationship between these two sets of constructs was found to be positive as well as product category specific. Furthermore, each consumer-based brand equity dimension contributed differently to the relationship according to the product category, while the contribution of both country image dimensions (macro and micro) was also product category specific. Results also showed that cars, as a product category, are more sensitive to country image than televisions. These findings have direct and important implications for international marketers [21]. Also Yasin et al., (2007) concluded that commercial brand's country of origin image had positive and significant effect on dimensions of brand equity including brand distinctiveness, brand loyalty, brand association and brand awareness [6]. Results Zeugner-Roth et al (2008) indicate that both marketing activities and PCI affect retailer-perceived brand equity with product-country images also strongly and positively influencing brand profitability performance [22]. Results Norouzi et al (2011) show that Brand Loyalty and Brand Awareness and Brand Association have direct influence on brand equity and also brand's country-of-origin image has direct influence on all for variants of Brand discrimination, Brand Loyalty Brand Awareness and Brand Association thus image of Brand's country-of-origin has direct influence on brand equity from the aspects of medium influences, Brand Distinctiveness, Brand Loyalty, Brand Awareness and-Brand Association [23]. The results Moradi and Zare (2012), indicated that the image of the factors brand equity and brand equity is total [24]. Finding Ranjbarian et al (2013) indicates that the effect of origin country of brand on brand strength and awareness and brand equity is positive and significant, while the effect of brand strength on brand equity is rejected [25]. Findings Rasha\& Mostafa. (2015) indicate that both COB and COM have direct and significant effect on CBBE, yet COM has significant lower effect on CBBE. In addition, $\mathrm{COB}$ and COM have direct influence on the overal brand equity [19].

\subsection{Research Hypotheses}

Based on discussions, these hypotheses are proposed:

H1. Perceived quality, brand loyalty and brand awareness/association have direct effect on brand equity.

H2. Brand's country-of-origin image will have a positive relationship with Perceived quality, brand loyalty, and brand awareness/associations.

H3. Brand country of origin image will have a positive relationship with brand equity through the mediating effects of brand distinctiveness, brand loyalty, and brand awareness /associations.

\subsection{Theoretical Framework}

In this research, Yoo\& et al. (2000) Model has been used which relates to relationship between brand country of origin image and brand equity using a balancing variable named dimensions of brand equity, and has been investigated by Yasin et al, (2007). In that study, the results of practical analysis shows that variable balancing dimensions include brand distinctiveness, brand loyalty, brand association and brand awareness [21]. Based on Aaker's definitions, brand loyalty can be defined as the extent to which customer has a positive attitude to word a brand, and the amount of his/her commitment to mentioned brand and intention of continuing buying in future. Brand association includes anything which is associated mentally with brand in memory. Brand awareness is the buyer's potential ability to recognize or remember the brand belongs to special class of product [13]. In this model, the country-of origin image is treated as the independent variable, the dimensions of brand equity as the mediating variables and brand equity as the dependent variable. The brand equity construct shows how individual dimensions of brand equity are related to the brand equity. The antecedent of brand equity is related to brand equity through the mediation of the dimensions of brand equity. Therefore, to create, to manage, and to exploit brand equity, the relationship between the dimensions of brand equity and brand equity, and the relationships between the antecedents and brand equity dimensions must be determined.

Due to the characteristics of Sports clothing, the importance of brand equity is very high in these products and usually product selection in the industry is based upon the brand made [26]. Since country of origin could be one of the influencing factors in determining consumers' choice, the purpose of this study is to explore the effects of brand's country-of-origin The current issue and full text archive of this journal is available a image on the formation of brand equity. To accomplish this goal, the brand equity of sport Clothing, in the Iran market is examined.

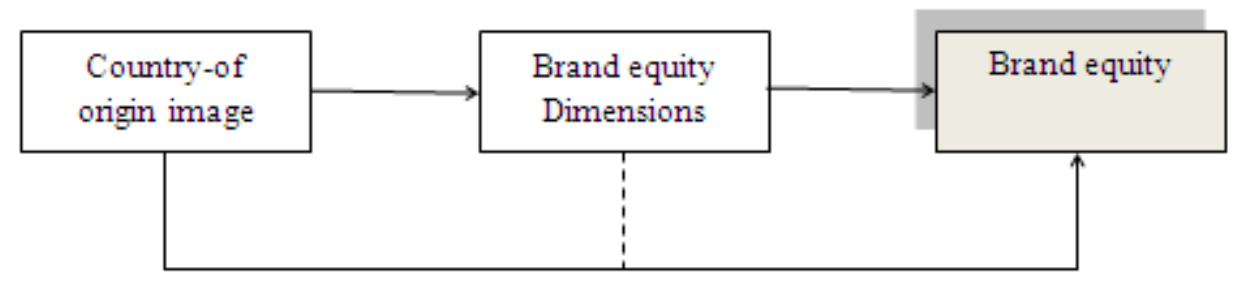

Figure 1. A conceptual framework of brand equity 


\section{Methodology}

Method of research was descriptive survey, which was based on Structural Equation Model (SEM) and was performed in the field study.The Population of the study was the whole physical education students and alumni Iran, which 805 subjects were selected based on the Purposive Sampling using in person, and online questionnaires from all the provinces of Iran. Furthermore, Tehran, Kermanshah, and Isfahan have formed the largest number of research subjects. Questionnaire contains 35 questions, in which Likert scale of five scores has been used. This questionnaire has been used by researchers like Yasin et al, (2007) and Yoo\& et al. (2000).Cronbach's alpha was applied to measure the inter-item consistency of the research constructs. The study multi-dimensional constructs Cronbach's alpha scored as follows: country of origin of brand (COB) (0.83), brand loyalty (0.79), perceived quality (0.88), brand awareness $(0.87)$, and overall brand equity (OBE) (0.74) respectively. Clearly all the research multi-dimensional constructs exceeded the suggested benchmarks for reliability $(0.6)$ stated by Nunnally and Bernstein (1994), hence illustrating internal consistency between the items used.Moreover, confirmatory factor analysis was used to test all questions with factor loadings above 0.5 validated the questionnaire. The study investigated the effects of the research variables using path analysis with SPSS 20 software and structural equation model (SEM) with Lisrel 8.80 software.

\section{Results}

\subsection{Sample Demographics}

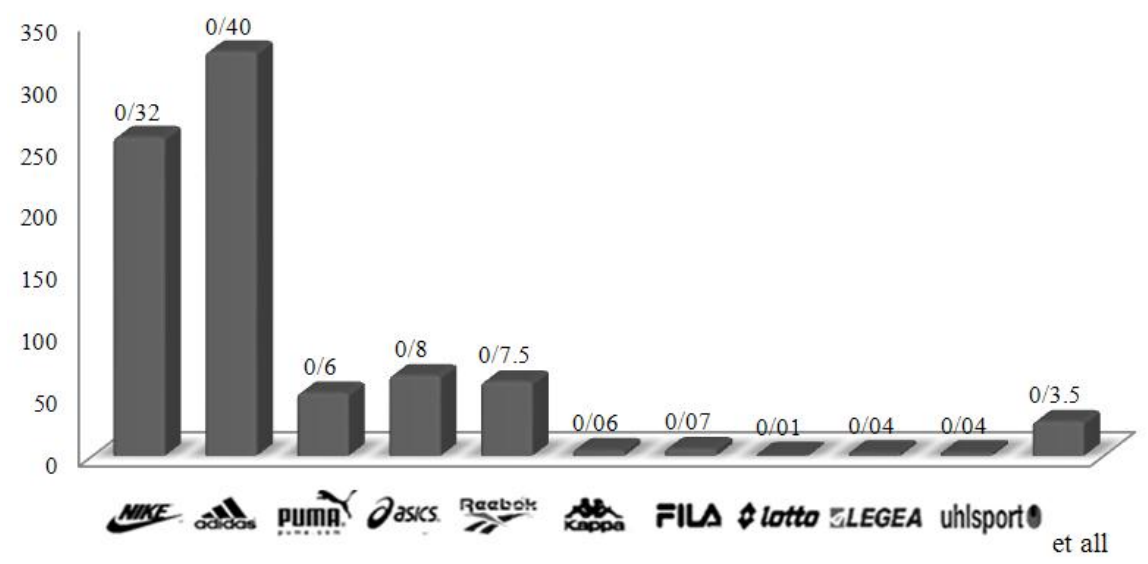

Figure 2. The frequency and frequency selective brands

Table 1.Pearson correlation coefficient, between Dimensions Research.

\begin{tabular}{|c|c|c|c|c|c|c|c|c|}
\hline & Variable & M & SD & 1 & 2 & 3 & 4 & 5 \\
\hline 1 & Brand Equity & 3.62 & .88 & 1 & & & & \\
\hline 2 & Perceived quality & 4.28 & .74 & $.464 * *$ & 1 & & & \\
\hline 3 & $\begin{array}{l}\text { Brand awareness } \\
\text { /associations }\end{array}$ & 4.07 & .77 & $.599 * *$ & $.658 * *$ & 1 & & \\
\hline 4 & Brand loyalty & 3.48 & .93 & $.531 * *$ & $.578 * *$ & $.623 * *$ & 1 & \\
\hline 5 & Country of Origin Image & 4.03 & .81 & $.608 * *$ & $.480 * *$ & $.497 * *$ & $.506 * *$ & 1 \\
\hline
\end{tabular}

The sample consisted of 805 subjects, which were $48 \%$ male and $52 \%$ female respondents, that $82 \%$ were married and $\% 18$ were intended to marry soon. The age of the sample shows that $9 \%$ of the subjects were less than 20 years, $56 \%$ between 21-25 years, 24\% between 26-30 years, and over 30 years were the $11 \%$. The study also found that those subjects had Diploma 11\%, BA 49\%, MA 35\%, and PhD 5\%. The largest were 394 individuals, which were associated with a master's degree.

\subsection{Choice Sports Brand}

Figure (2) contains the top 10 international famous sports brand in the world. In this question, the respondents were asked, which of the foreign brands they prefer (choosing one option). As is evident in Figure 1, the two are foreign brands Adidas and Nike alone accounted 0.72 selected brands.

\subsection{Correlation Coefficient, between Dimensions Research}

Pearson correlation test results between Brand Equity, Dimensions Brand Equity and Brand Country-of-Origin Image shown in Table (1). The result indicates existing positive and significant relationship between all the variables. As can be seen, between all brand equity dimensions and brand equity, positive relationship, with significant top is in place. Interestingly, there is a high correlation between Brand Country-of-Origin Image and brand equity (0.608). Its meaning is that, by promoting sports brand equity, increase brand image and mentality than the Brand Country-of-Origin Image.

Note. $\mathrm{P} \leq 0.05$ 


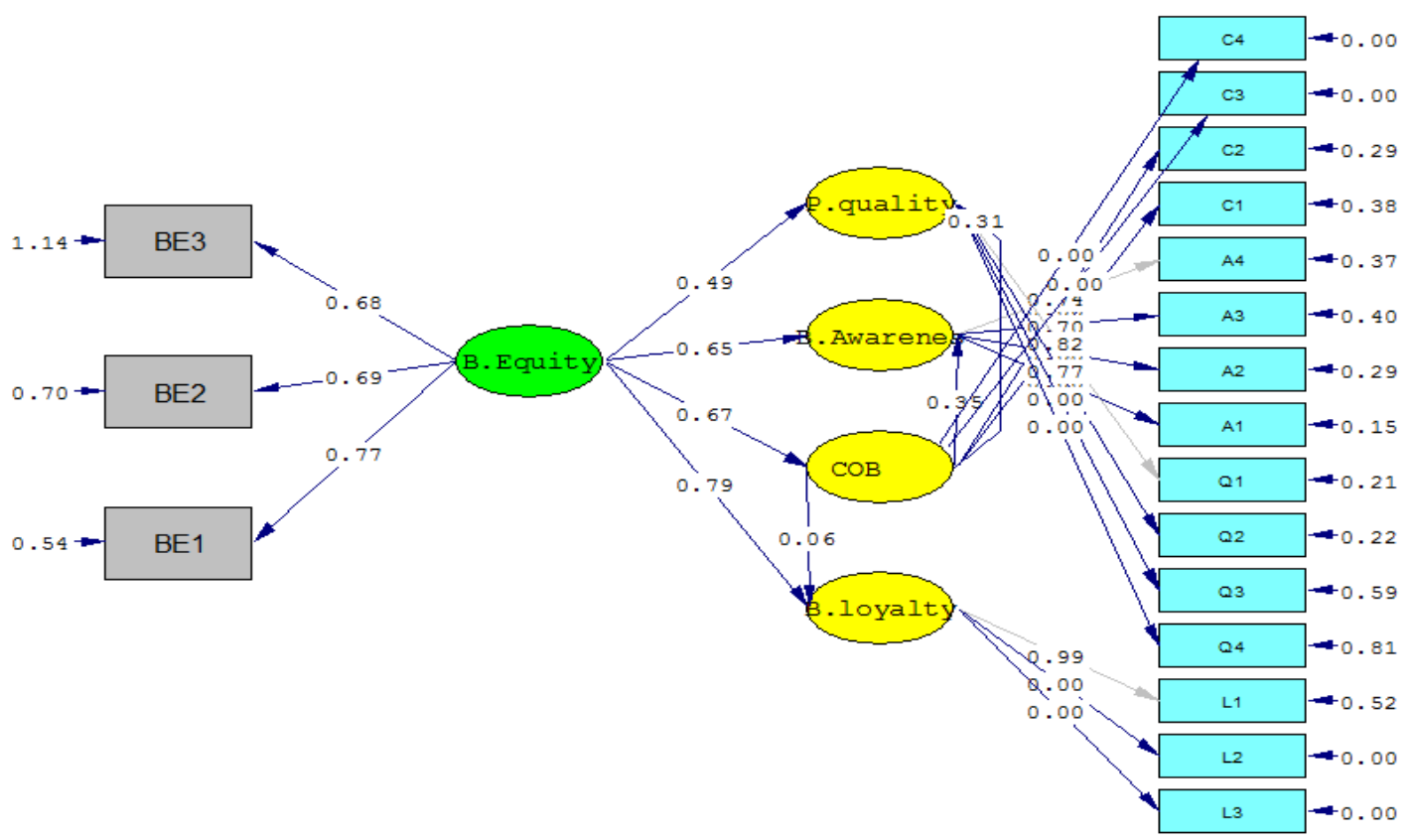

Chi-Square=777.55, df=228, P-value=0.00000, RMSEA=0.079

Figure 3. LISREL output to research model

Table 2. Test for goodness of fit research

\begin{tabular}{ccccccccc}
\hline fit indices & $\chi^{2} / \mathbf{d f}$ & RMSEA & RMR & NFI & NNFI & CFI & GFI & AGFI \\
\hline acceptable & $5<$ & $0.1<$ & $0.1<$ & $0.9>$ & $0.9>$ & $0.9>$ & $0.9>$ & $0.9>$ \\
Value & 3.41 & 0.079 & 0.058 & 0.97 & 0.97 & 0.98 & 0.90 & 0.87 \\
\hline
\end{tabular}

\subsection{Testing the Research Model}

The research hypothesis testing, analysis of structural equation was used. Significance level of the test standard coefficient $\mathrm{T}$ is determined. T-Degree standard is more than 1.96 , meaning hypothesis was at 0.95 . The study showed the standardized regression weights in Figure (3).

The model is significant at $\mathrm{p} \leq 0.05$ indicating 95 percent confidence in the independent variables namely: CBBE dimensions in explaining the dependent variable OBE. All four variables are found to have a significant and positive influence on OBE at a significant level indicates. That brand loyalty has the highest influence on $\operatorname{OBE}(0.79)$. But between brand's country of origin image and brand loyalty, the effect was not significant $(\mathrm{t}=1.23)$. In other words, Findings SEM show that brand's country of origin image has a direct effect on dimensions of brand equity, and represented of them, and as mediation effect has positive and significant effect on brand equity, whose effect is $0.67 \%$ $(\mathrm{t}-\mathrm{value}=15.51)$.

Given the values of the indicators proposed for this model in Table (2), as can be seen, the value of $\chi^{2}$ the degree of freedom it was less than 5 , the model confirmed. The fit indices NFI, NNFI, CFI, IFI and GFI greater than 0.9 , RMSEA, and RMR is smaller than 0.08, which confirmed the validity of this model.

\subsection{Hypotheses Testing}

Findings obtained from structural equation modeling for testing the research hypotheses are as follows:

\subsubsection{Testing the Hypothesis 1}

Results show that dimensions of brand equity have direct effect on brand equity. The numbers obtained for the in t-value model were 9.90, 13.33 and 14.38 for Perceived quality, brand loyalty and brand awareness/association respectively. Findings reveal that two variables of brand loyalty and brand awareness have direct effect on Brand equity. so research hypothesis is accepted. Therefore, with regards to results we can say that increasing the awareness and planning programs for increasing brand loyalty are key factors of increasing brand equity for Sports clothing manufacturers, however in this sense the role of brand loyalty is more significant $(0.79)$. The results are shown in Table (3).

Table 3. The effect of Dimensions Brand Equity on Brand Equity

\begin{tabular}{lcccc}
\hline Independent variables & $\begin{array}{c}\text { Dependent } \\
\text { variable }\end{array}$ & $\begin{array}{c}\text { Std. } \\
\text { Beta }\end{array}$ & $\begin{array}{c}\boldsymbol{t} \text { - } \\
\text { value }\end{array}$ & $\begin{array}{c}\text { Sig. } \boldsymbol{p} \text { - } \\
\text { value }\end{array}$ \\
\hline Perceived quality & Brand Equity & 0.49 & 9.90 & .001 \\
Brand loyalty & Brand Equity & 0.79 & 13.33 & .001 \\
$\begin{array}{l}\text { Brand } \\
\text { Awareness/associations }\end{array}$ & Brand Equity & 0.65 & 14.38 & .001 \\
\hline$\leq 0.005$ & & & &
\end{tabular}

3.5.2. Testing the hypothesis 2 
Findings Table (4) show that brand's country of origin image has direct effect on Perceived quality, $0.31 \%$ (t-value $=6.51)$ and awareness/association, $0.35 \%(\mathrm{t}$-value $=8.07)$. However country-of-origin of brand (COB) has no direct effect on brand loyalty $(\mathrm{t}$-value $=1.13$ ). Therefore regarding to results, we can say that suitable brand's country of origin image for Sports clothing sets has significant effect on variables of Perceived quality, brand awareness, and brand association which collectively increase brand equity. The results are shown in Table (4).

Table 4. The effect of Country of Manufacture (COM) on Dimensions Brand Equity

\begin{tabular}{ccccc}
\hline $\begin{array}{c}\text { Independent } \\
\text { variable }\end{array}$ & Mediating variables & $\begin{array}{c}\text { Std. } \\
\text { Beta }\end{array}$ & $\begin{array}{c}\boldsymbol{t} \text { - } \\
\text { value }\end{array}$ & $\begin{array}{c}\text { Sig. } \\
\boldsymbol{p} \text { - } \\
\text { value }\end{array}$ \\
\hline $\begin{array}{c}\text { Country of } \\
\text { origin of brand } \\
\text { Country of } \\
\text { origin of brand } \\
\begin{array}{c}\text { Country of } \\
\text { origin of brand }\end{array}\end{array}$ & Perceived quality & 0.31 & 6.51 & .001 \\
\hline
\end{tabular}

$p \leq 0.005$

\subsubsection{Testing the Hypothesis 3}

In Table (4) shows the relationship between country-of-origin of brand (COB) and brand equity. Obtained numbers of $t$-value show the significance of effect between country-of-origin of brand (COB) and brand equity (Std. $\beta$ eta $=0.35 \%$ \& $\mathrm{t}$-value $=8.07$ ). So we can conclude that hypothesis 3 is accepted. The results are shown in Table (5).

Table 5. The effect of Country of Origin of Brand (COB) on Brand Equity

\begin{tabular}{ccccc}
\hline $\begin{array}{c}\text { Independent } \\
\text { variable }\end{array}$ & $\begin{array}{c}\text { Dependent } \\
\text { variable }\end{array}$ & $\begin{array}{c}\text { Std. } \\
\text { Beta }\end{array}$ & $\begin{array}{c}\boldsymbol{t} \text { - } \\
\text { value }\end{array}$ & $\begin{array}{c}\text { Sig. } \boldsymbol{p} \text { - } \\
\text { value }\end{array}$ \\
\hline $\begin{array}{c}\text { Country of origin } \\
\text { of brand }\end{array}$ & Brand Equity & 0.67 & 15.51 & .001 \\
\hline
\end{tabular}

$p \leq 0.005$

\section{Discussion and Conclusions}

This research which addressed the relationships between brand's country of origin image and brand equity in the sports apparel industry by taking into account the balancing effect of brand equity dimensions proved this fact. The results indicate existing positive and significant relationship between all the variables brand equity. However, among the all brand equity dimensions, Brand loyalty had the highest impact on brand equity, indicating the importance of quality in building Sports brand equity. This result is Similar with Yoo et al. (2000) and Kim and Kim (2004) who reported that brand loyalty had the major impact on overall brand equity (Rasha\& Mostafa, 2015). Since the relationships of the three dimensions of brand equity to brand equity are positive, we can say that, the more distinctive the brand is, the higher the brand equity. Similarly, a high degree of brand loyalty and brand awareness leads to a high level of brand equity. In terms of the effect size, brand loyalty seems to contribute the most to the formation of brand equity. This is in line with the works of Yoo et al. (2000) that found brand loyalty as the key construct in explaining brand equity (Yasin et al, 2007). Further, the effect of country of origin of brand (COB) on consumer-based brand equity dimensions (CBBE) was also investigated. The results indicated positive and significant relationships between $\mathrm{COB}$ and every dimension of CBBE. This result complies with Pappu et al. (2006), Yasin et al (2007), and Moradi and Zarei (2012), and (Rasha\& Mostafa, 2015).Country-of-origin image plays an important role in consumer purchase decision. Consumers develop their interest and preference for a brand on the basis of their perception of the country-of-origin and the available information pertaining to the brand. As such, favorable information about the country helps creates positive attitude toward the brand, which leads to favorable image of the brand. Jacoby et al (1971) suggested that brand image has a strong effect upon quality perception. Since brand distinctiveness in this study refers to favorable and positive aspects that are associated to the brand, such as quality, this suggests that favorable country image leads to favorable brand image, which in turn influences brand distinctiveness. This explains the positive and significant relationship between country image and brand distinctiveness (Yasin et al, 2007).

The study revealed that all CBBE dimensions fully mediate the relationship. Brand managers will have to take $\mathrm{COB}$ into consideration while marketing for their brands internationally. They also have to manage their CBBE dimensions effectively as long as they fully mediate the relation between COM and overall brand equity. As well as The results of this research show that brand's country of origin image has an important role in promoting the brand equity. In other words, brand's country of origin image effects the brand equity. So, producers and owners of brand should pay attention to this, and try to shap desirable image in consumer's mind during the time. On the other hand, results show that brand loyalty has the most effect on brand equity. So planning and operating loyalty programs such as club for company's customers, performing suitable programs and conferences for customers, creating desirable relation with customers and maintaining and promoting product's quality and other similar procedures will have a high effect on increasing brand equity in long term. Also producers should try to promote brand's country of origin image to increase brand image in markets by using advertisements and other combined components such as personal sales and public relations. Also, it is recommended that research like investigating the effect of brand equity dimensions on companies financial performance once is conducted, together with similar research with considering the products in different classes and different statistical societies in terms of income level, geographical zones, and educational levels to make clear other dimensions of the concept. 


\section{REFERENCES}

[1] Askarian, F. Economic situation in the sports industry in the years 1998 and 2001. PhD Thesis, Tehran University, Faculty of Physical Education and Sport Sciences, Tehran, Iran.2004. [PhD Thesis in Persian].

[2] Ko,E., Taylor, C., Sung, H. Lee, J, Wagner, U., Navarro,D,Wang, F. Global marketing segmentation usefulness in the sportswear industry. Journal of Business Research. 2012, 65:1565-1575.

[3] Kapfrr, J N. Strategic brand management. Cena translating Lu sir, missionaries Publications, Tehran, first printing. 2006.

[4] Rafiee, S, Haghighi, M., Yazdani, HR. The impact of marketing mix on brand equity and corporate image software sector of IT industry. Journal a new market research study. 2012, 2 (4): 182- 195. [Article in Persian].

[5] Yoo, B., Donthu, N., \& Lee, S. An Examination of Selected Marketing Mix Elements and Brand Equity. Journal of the Academy of Marketing Science. 2000, 28(2): 195-211.

[6] Yasin, N., Noor, M., \& Mohamed, O. Does Image of Country-of-Origin Matter to Brand Equity? Journal of Product and Brand Management. 2007, 16(1): 38-48.

[7] Paswan, A.K. D. Sharma. Brand country of origin (COO) knowledge and coo image: investigation in an emerging franchise market, Journal of Product \& Brand Management. 2004, 13(3): 144-55.

[8] Wang, C. and C. Lamb. The impact of selected environmental forces upon consumers' willingness to buy foreign products. Journal of the Academy of Marketing Science. 1983, 11(2): 71-84.

[9] Farquhar, P.H. Managing brand equity. Marketing Research. 1998, 24-33.

[10] Kim, H.B., W.G. Kim and F.A. AN. The Effect of Consumer- based brand equity on firms, Financial Performance, Journal of Consumer Marketing. 2003, 20(4): 33-51.

[11] Bendixen, M., K. Bukasa and R. Abratt. Brand Equity in the Business-to-Business Market, Industrial Marketing Management. 2003, 33: 371-380.

[12] Keller, K. L. Brand Synthesis: The Multi dimensionality of Brand Knowledge. Journal of Consumer Research. 2003, 29(4): 595-600.

[13] Aaker, D. A. Managing Brand Equity. New York, NY: the Free Press. 1991.
[14] Kapferer, J.N. Strategic brand management, The Free Press, New York, NY. 1992.

[15] Aaker, D. A. Measuring brand equity across products and markets. California Management Review. 1996, 38(3): 102-120.

[16] Keller, K. L. Conceptualizing, Measuring, and Managing Customer-Based Brand Equity. Journal of Marketing. 1993, 57(1): 1-22.

[17] Khan, M., \& Mahmood, Z. Impact of Brand Loyalty Factors on Brand Equity. International Journal of Academic Research. 2012, 4(1): 33-37.

[18] Yoo, B., \&Donthu, N. Testing Cross Cultural Invariance of the Brand Equity Creation Process. Journal of Product and Brand Management. 2002, 11(6): 380-398.

[19] Rasha H. A. Mostafa. The Impact of Country of Origin and Country of Manufacture of a Brand on Overall Brand Equity. International Journal of Marketing Studies. 2015. 7 (2): 70-83.

[20] Piron, F. Consumers' perceptions of the country-oforigin effect on purchasing intentions of (in) conspicuous products. Journal of Consumer Marketing. 2000, 17 (4): 308-21.

[21] Pappu, R., Quester, P. G., \& Cooksey, R. W. (2006). Consumer-based brand equity and country-of-origin relationship: some empirical evidence. European Journal of marketing. 2006, 40(5/6), 696-717.

[22] Zeugner-Roth, K. P., Diamantopoulos, A., \&Montesinos, M. A. Home country image, country brand equity and consumers' product preferences: an empirical study. Management International Review. 2008, 48(5): 577-602.

[23] Norouzi, A. FallahHosienabadi, B. The Effects of Brand's Country-of-Origin Image on The Formation of Brand Equity.Australian Journal of Basic and Applied Sciences. 2011, 5(12): 766-770.

[24] Moradi, H., \&Zarei, A. Creating Consumer Based Brand Equity for Young Iranian Consumers via Sub-Components Country of Origin Effects. Asia Pacific Journal of Marketing and Logistics. 2012, 24(3): 394-413. [Article in Persian].

[25] Ranjbarian, B. Mahmoudi, E. Ghasemi.A. The Effect of Country of Origin of Brand on Brand Equity. Asia Pacific Journal of Marketing and Logistics. 2013, 18(1): 63-74. [Article in Persian].

[26] Azadi, R. The relationship between selectedelements of marketing mix and brand equity agents sports apparel among students and graduates of Physical Education and Sports Science. Faculty of Physical Education and Sports Science Department of Sports Management in Raziuniversity, Kermanshah, Iran. 2014, [M.Sc.Thesis in Persian]. 